\title{
Mulige NP-placeringer ved retningsadverbium + præposition
}

\author{
MICHAEL NGUYEN
}

\begin{abstract}
I denne artikel analyseres konstruktioner hvor en NP (nominalfrase) står til venstre for et retningsadverbium, fx Australien rundt, livet ud og et andet sted hen, og konstruktioner hvor NP'en står til højre for retningsadverbiet (og en præposition), fx rundt om Australien, ud $i$ livet og hen til et andet sted. Den fremlagte analyse bygger på generative standardantagelser om hvordan frasestrukturer ser ud, og om hvordan NP'er tilskrives kasus, herunder at en NP skal tilskrives én og kun én kasus. Analysen bygger også på at en såkaldt $p$ P-konstituent eksisterer, dvs. en konstituent hvor retningsadverbiet $p$ er en kerne der selekterer en PP (præpositionalfrase), fx $\left[_{p \mathrm{P}}\right.$ rundt $\left[_{\mathrm{PP}}\right.$ om Australien]]. Det er desuden en vigtig antagelse at $p$-elementet kan selektere en PP med en implicit eller "usynlig" præposition P (dvs. et slags nulmorfem). Med udgangspunkt i $p$ P-strukturen og alle de nævnte antagelser redegør analysen for hvorfor konstruktioner som rundt om Australien og Australien rundt er grammatiske, hvorimod konstruktioner som * rundt Australien og *Australien rundt om er ugrammatiske. I de grammatiske tilfælde får NP'en tilskrevet én og kun én kasus, enten af et p-element eller af P. I de ugrammatiske tilfælde får NP'en hhv. ingen kasus eller to kasus.
\end{abstract}

EMNEORD: kasus, retningsadverbier, præpositioner og postpositioner, $p \mathrm{P}$, generativ lingvistik

\section{INDLEDNING}

Denne artikel tager udgangspunkt i konstruktioner hvor en nominalfrase (NP) er foranstillet et retningsadverbium. Konstruktionerne har altså formen 'NP + retningsadverbium'. Se eksemplerne nedenfor (de relevante konstruktioner er i fed):

a. I dag er Ole Nydahl selv lama med 110 centre jorden rundt.

b. Det var på det tidspunkt længe siden, han havde skrevet digte. Livet ud bebudede han nye digte, og alle håbede. 
c. Dag ud og dag ind vandrede han afsted ad landevejen ...

a. Han kører alle turister det samme sted hen.

b. I 1971 sejlede jeg Australien rundt i en åben 16-fods båd. (Eksemplerne er fra KorpusDK.)

Fælles for konstruktionerne i (1) er at de betegner udstrækning, hvad enten der er tale om rumlig eller tidslig udstrækning (se Nguyen 2020a: 36-76, 262-274, 2020b: 98-101, A. Kobayashi 2014: 18-19). Jorden rundt betyder noget i retning af 'overalt på jorden' eller 'mange steder (rundtomkring) på jorden'. Livet ud betyder her noget i retning af 'hele hans liv' eller 'hele resten af hans liv', og dag ud og dag ind betyder 'hver eneste dag i en lang periode' (se Den Danske Ordbog under opslagsordet ind). Udstrækningssemantikken ved de temporale konstruktioner medfører at de ikke kan kombineres med prædikater som udtrykker punktuelle begivenheder, $\mathrm{fx} *$ Han faldt om dag ud og dag ind (Nguyen 2020a: 74-75, 273-274, 2020b: 101).

Fælles for konstruktionerne i (2) er at de betegner bevægelse. Australien rundt $\mathrm{i}(2) \mathrm{b}$ er dog i princippet tvetydig. Ud fra konteksten er det klart at Australien rundt betyder 'rundt om Australien', men det kan også betyde noget i retning af 'mange steder (rundtomkring) i Australien', altså en betydning der minder om den i (1)a (se Aa. Hansen 1967: 308, Nguyen 2020b: 100-101). Denne betydning er mere sandsynlig hvis det område der besejles har mange floder og kanaler, men dette er ikke tilfældet i Australien rundt.

Konstruktionerne med foranstillet NP bør skelnes fra verbalpartikelkonstruktionerne, fx Han kørte Peter hjem eller Han smed bogen $u d$. I verbalpartikelkonstruktionerne er verbet typisk trykreduceret, og retningsadverbiet er tæt knyttet til verbet (se fx Harder et al. 1996, Thomsen 1998). I konstruktionerne med foranstillet NP er verbet ikke nødvendigvis trykreduceret, og retningsadverbiet behøver ikke at være tæt knyttet til verbet: Konstruktionerne kan endda fungere som 'frie led' (Nguyen 2020a: 19, 2020b: 91, 2021b: 420), se (1). Eksempler på at konstruktionerne nogle gange kan kombineres med verbalpartikelkonstruktioner, kan ses i (2). 
Danske grammatikker har generelt ikke beskæftiget sig meget med konstruktionerne med foranstillet NP. Allan et al. (1995: 379), Diderichsen (1976 [1946]: 248), Aa. Hansen (1967: 307-311), Falk \& Torp (1900: 313) og Mikkelsen (1975 [1911]: 370-371) nævner nogle af dem ganske kursorisk, mens E. Hansen (2006 [1977]), Christensen \& Christensen (2014 [2005]) og E. Hansen \& Heltoft (2011) ikke nævner dem. Jeg har dog i nyere publikationer behandlet disse konstruktioner nærmere (se Nguyen 2020a,b, 2021a). I disse publikationer foreslår jeg at retningsadverbiet er en postposition (eller bruges som en postposition), og at den foranstillede NP er postpositionens komplement, altså dens styrelse (se også Nguyen 2021b).

Formålet med denne artikel er at præsentere en generativ analyse der skal forklare hvorfor konstruktioner som dem i (3) og (4) er hhv. grammatiske og ugrammatiske:
a. Australien rundt
b. Rundt om Australien
c. Livet ud
d. Han sprang ud i livet med stor begejstring.
a. *Australien rundt om
b. $\quad *$ Rundt Australien
c. $\quad *$ Ud livet
d. $\quad *$ Han sprang livet ud i med stor begejstring.

NP'en kan altså både stå til venstre for retningsadverbiet, se (3)a/(3)c, og til højre for retningsadverbiet (med en præposition), se (3)b/(3)d. Men disse ordstillingsvariationer er ikke altid mulige, se (4). Den traditionelle forskningslitteratur har ikke eksplicit og utvetydigt i noget særligt omfang været opmærksom NP’ens position både til højre og til venstre for retningsadverbiet, og det er antageligvis derfor den heller ikke har diskuteret de ugrammatiske konstruktioner i (4). Denne mangel vil jeg forsøge at råde bod på i denne artikel.

Bemærk at der nok ikke er noget semantisk eller pragmatisk galt med 
konstruktionerne i (4), men derimod noget syntaktisk. Min analyse giver en mulig syntaktisk forklaring på hvorfor konstruktionerne i (3) er grammatiske, hvorimod konstruktionerne i (4) er ugrammatiske.

Resten af artiklen er struktureret på følgende måde: Afsnit 2. handler om fundamentet for den generative analyse; i afsnit 3 fremlægges selve analysen; og i afsnit 4 diskuteres en række problemer og udestående spørgsmål. Endelig sammenfattes artiklens hovedpunkter i afsnit 5 .

\section{FUNDAMENTET FOR ANALYSEN}

For at kunne fremlægge min analyse er det nødvendigt først at klargøre hvilket fundament analysen bygger på. Analysen bygger først og fremmest på standardantagelser der angår frasestrukturen (2.1), og som angår kasus (2.2). Derudover bygger analysen på at den konstituent jeg kalder $p$ P, eksisterer, og på at denne konstituent har en bestemt struktur (2.3).

\section{1 standardantagelser angående frasestrukturen}

Terminologien i forbindelse med træstrukturer kan illustreres med følgende figur:
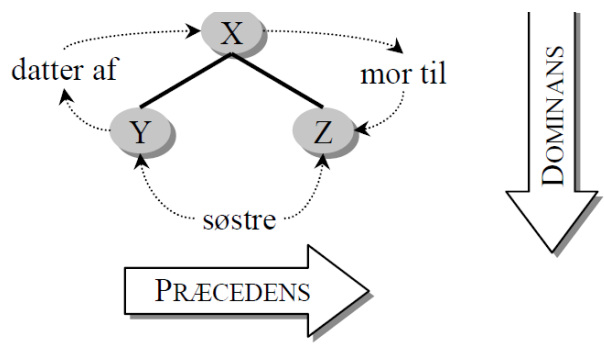

$\mathrm{X}$ er mor til $\mathrm{Y}$ og $\mathrm{Z}$,

$Y$ og Z er døtre af $X$,

Y og Z er søstre.

$\mathrm{X}$ dominerer $\mathrm{Y}$ og Z.

Y står før Z

(FIGUREN ER FRA (1) I VIKNER 2013: 468 OG ER LAVET AF KEN RAMSHØJ CHRISTENSEN OG STEN VIKNER.)

For nærværende er det vigtige i figuren termen søSTER, og herunder at elementer kan være søstre til hinanden. Der er derudover en række vigtige begreber i forbindelse med strukturen $\mathrm{i}$ en frase (= et syntagme = en XP, en forkortelse for engelsk 'X phrase', dvs. en frase af kategorien 
X). Se følgende træstruktur, hvor alle X'erne står i stedet for en hvilken som helst kategori:

(6) Strukturen i en frase (= et syntagme = en XP)

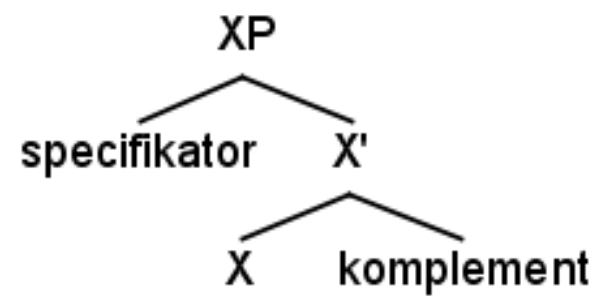

Denne struktur gælder for alle fraser: Hvis man i ovenstående struktur erstatter alle X'erne med Adj (adjektiv), får man en AdjP (adjektivfrase), og hvis man erstatter X'erne med $\mathrm{P}$ (præposition), får man en PP (præpositionalfrase) osv. Jeg vil i det følgende bruge forkortelser som $\mathrm{V}, \mathrm{P}$ og PP for at henvise til konstituenterne i en træstruktur som (6).

Som man kan se i (6), er SPECIFIKATORPositionen (forkortes XPspec) søsteren til konstituenten X' (læses 'X-bar'). Søsteren til kernen $\mathrm{X}$ er Komplementpositionen, og komplementet er selekteret af kernen $\mathrm{X}$ (dette er den samme indsigt som ligger bag begrebet valens). Fx er komplementet til $\mathrm{V}$ typisk det direkte objekt, mens komplementet til P er dens styrelse.

Begreberne frase, specifikatorposition, kerne og komplement(position) er vigtige for analysen i afsnit 3. Man kan diskutere om specifikatorpositionen altid er der, også når der ikke står noget i den. I træstrukturerne nedenfor inkluderer jeg kun specifikatorpositionen og X'-konstituenten når der står noget i specifikatorpositionen, eller når det fremmer formidlingen.

Jeg har nu introduceret nogle centrale begreber indenfor frasestrukturen. $\mathrm{Nu}$ skal et andet vigtigt begreb introduceres, nemlig Kasus.

\section{2 standardantagelser angående kasus}

Min analyse forudsætter tre standardantagelser om kasus indenfor generativ lingvistik (se fx Baker 2013 for en indføring). Bemærk at jeg af formidlingsmæssige årsager vil forenkle forklaringen af disse tre antagelser. 
Den første antagelse er at alle NP'er (uanset om de er pronominer eller ej) skal tilskrives kasus. Kasus i generativ forstand behøver altså ikke at have en morfologisk realisering, ligesom den der findes ved pronominerne.

Den anden antagelse er at en NP skal have én og kun én kasus. Med andre ord: Hvis en NP ikke har kasus, eller hvis en NP har mere end en kasus, giver det et ugrammatisk resultat. Dette er det såkaldte kasusfilter (Chomsky 1981: 49ff., Vergnaud 1977).

Den tredje antagelse er at en NP får tilskrevet kasus af en kerne, herunder af V og af P. Dette forudsætter dog at NP'en står i en bestemt position i forhold til denne kerne. Der er to positioner hvor en NP kan få tilskrevet kasus fra denne kerne: enten i specifikatorpositionen til kernen eller i komplementpositionen til kernen.

Disse tre antagelser om kasus er vigtige for analysen fordi kombinationen af dem forudsiger hvilke konstruktioner der er mulige og umulige.

\subsection{Nyt bidrag til analyseapparatet: $\mathrm{p} P$-konstituenten}

I de foregående to underafsnit har jeg indført nogle standardantagelser i generativ lingvistik. Jeg vil nu gå videre og foreslå at der findes en $p$ P-konstituent, hvilket ikke kan siges at være en standardantagelse. $p$ P'ens struktur er illustreret i (7) og eksemplificeret i (8); (9) giver en detaljeret analyse af (8)b. Trekanten i (7) og (9) signalerer at NP'ens indre struktur for nærværende ikke er relevant, og derfor ekspliciteres NP'ens struktur ikke yderligere i træstrukturen.

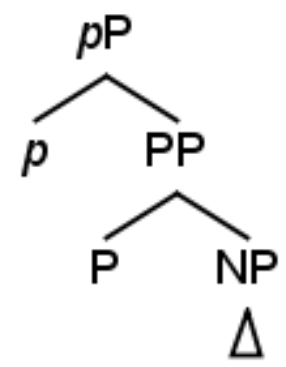


(8)

a. Han kørte $\left[{ }_{p P}\right.$ hen/ind/over/ud $\left[_{\mathrm{PP}}\right.$ på $\left[{ }_{\mathrm{NP}}\right.$ havnen $\left.\left.]\right]\right]$.
b. Han kørte $\left[{ }_{p P}\right.$ rundt $\left[_{\mathrm{PP}}\right.$ om $\left[_{\mathrm{NP}}\right.$ bageren $\left.\left.]\right]\right]$.

(9)

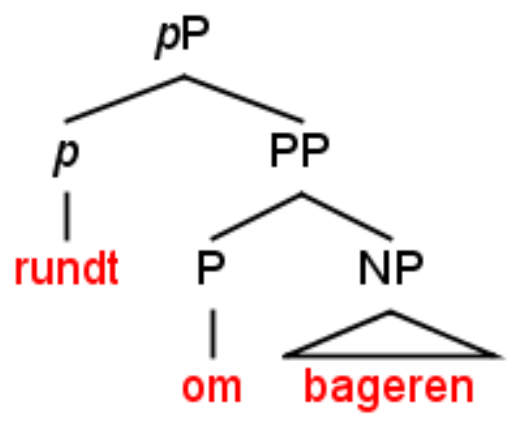

p-elementet er et retningsadverbium der selekterer en PP (dvs. en præpositionalfrase) som sit komplement, og tilsammen udgør ' $p+$ PP' konstituenten $p$ P. Groft forenklet udtrykker $p$ P begivenheden 'en entitet bevæger sig et andet sted hen og befinder sig endeligt på dette sted'. $p$-elementet betegner dels orientering ( $\mathrm{fx}$ 'op' eller 'ned'), dels translokation, altså bevægelse fra et sted til et andet, herunder også metaforisk bevægelse. PP'en giver information om entitetens endelige sted (målet for bevægelsen): NP'en udtrykker hvilket slags sted der er tale om, fx en havn eller en bager, og P udtrykker hvordan entiteten befinder sig i forhold til dette sted, fx på, ved eller omkring stedet (se mere detaljerede analyser og beskrivelser i bl.a. Bjerre 2003, Harder et al. 1996, Thomsen 1998 og Hovmark 2007). PP'er der ikke giver information om det endelige sted, er ikke en del af $p \mathrm{P}$ og er derfor irrelevante her, $\mathrm{fx}$ Han kører rundt [pP $_{\mathrm{PP}}$ på planen]. PP'en på planen giver ikke information om det endelige sted hvor han kører hen, fordi han ikke har bevæget sig hen på plænen, men blot holdt sig på den.

Det skal siges at $p$ P-strukturen i (7)-(9) på ingen måde er en ny opfindelse. Den samme struktur eller lignende strukturer findes bl.a. i Asbury et al. (2006), Ayano (2001), Gehrke (2007: 257), Helmantel (2002), Nguyen (2019a,c, 2020a), Riemsdijk (1990), Rooryck (1996) 
og Svenonius (2003, 2007).

Jeg vil nu argumentere for at $p \mathrm{P}$-strukturen findes, altså at der overhovedet er en konstituent der består af ' $p+$ PP' (2.3.1), og at $p$-elementet sandsynligvis er kernen i denne konstituent (2.3.2) (man kan også finde lignende opfattelser i ikke-generative analyser, se Becker-Christensen 2010: 227, Harder et al. 1996: 189-192, E. Hansen \& Heltoft 2011: 846, 1017, Thomsen 1998: 69).

\subsection{1'p + PP' er en konstituent}

Jeg vil første vise at strengen ' $p+$ PP' er en konstituent. Som vist $\mathrm{i}$ Nguyen (2019c: 127-128, 2020a: 134-138) tyder almindelige konstituenttests på at ' $p+$ PP' er en konstituent. Strengen kan flyttes (10)a, ${ }^{1}$ elideres (10)b og være et fragmentsvar (10)c:

a. [Ned gennem Tyskland] rejste Peter.

b. Peter rejste.

c. Taler A: Hvor rejste Peter hen?

Taler B: Ned gennem Tyskland.

(Konstruerede eksempler fra Nguyen 2020a: 134-135)

Men på baggrund af bl.a. følgende data er Risom (2005) uenig i at det jeg kalder ' $p$ + PP', er en konstituent:

a. Han gik ud i haven fordi der var sol.

b. I haven gik han ud fordi der var sol.

c. Haven gik han ud i fordi der var sol.

d. ??Ud gik han i haven fordi der var sol. ${ }^{2}$

e. ??Ud i haven gik han fordi der var sol.

(Tilpassede eksempler fra Risom 2005: 307, 309-310)

1 Diderichsen (1976 [1946]: 163) bruger også flytningstesten, endda med det samme verbum:

(i) Hjem til Ribe rejste han ikke.

2 Risom (2005: 310) angiver (11)d som grammatisk; jeg og andre talere accepterer den ikke uden videre. Derfor har eksemplet to spørgsmålstegn. 
Ret beset er det kun (11)e der er relevant for om 'p + PP' er en konstituent. De andre eksempler er irrelevante. (11)b-(11)d siger noget om hvorvidt de fremrykkede elementer er konstituenter, men ikke noget om hvorvidt ' $p+$ PP' er en konstituent. En streng kan sagtens være en konstituent samtidig med at den indeholder flere konstituenter.

Jeg vil altså fokusere på (11)e, som jeg selv mener er grammatisk i den rette kontekst, $\mathrm{fx}$ når ' $p+\mathrm{PP}$ ' er fokuseret. For at understøtte synspunktet om at ' $p+$ PP' er en konstituent, viser jeg naturligt forekommende data hvor ' $p+$ PP' er flyttet ved fremrykning til forfeltet og ved kløvning (bemærk at (12)a er et eksempel med flytning af den selvsamme streng som i Risoms eksempler):

a. Ud i haven kommer nu hans søn Lars [...]. (http://bassehansen.dk/wp-content/uploads/2017/06/ERIN DRINGER.pdf)

b. Det var ind i denne ovn, heksen blev skubbet af den snarrådige Grete.

(https://www.ravstedlokalhistorie.dk/index.php/erindringer/12-erindringer-ravsted/71-ravsted-fhv-skoleinspektorjohann-kirstens-barndomserindringer-fra-ravsted)

På baggrund af de konstruerede data i (10) og på baggrund af de naturligt forekommende data i (12) holder jeg derfor fast ved at ' $p+$ PP' er en konstituent; dette står i modsætning til Risoms analyse (2005).

\subsection{2 p-elementet er kernen $i$ ' $\mathrm{p}+P P^{\prime}$}

Jeg har ovenfor argumenteret for at strengen ' $\mathrm{p}+\mathrm{PP}$ ' er en konstituent. Det betyder dog ikke nødvendigvis at $p$-elementet er kernen i konstituenten i ' $p$ + PP' (på samme måde som P er kernen i en PP). Det vil jeg argumentere for i dette afsnit (se også fx Herslund 1984: 39).

Som den anonyme fagfælle pointerer, bør $p$-elementet ikke kunne fremrykkes ved kløvning hvis det er kernen i konstituenten ' $p+$ PP'. Fraser kan nogle gange fremrykkes ved kløvning, hvorimod kerner aldrig kan. Eksemplet nedenfor falsificerer i det mindste ikke ideen om at p-elementet er kernen i konstituenten ' $p+\mathrm{PP}^{\text {': }}$ 
*Det var ind, heksen blev skubbet i denne ovn af den snarrådige Grete.

(Sammenlign med (12)b.)

Hertil kommer et argument der handler om hvorvidt p-elementet kan udelades. Kernen i en konstituent kan som udgangspunkt ikke udelades. Som Nguyen (2019c: 124-125, 2020a: 138-140) og Hovmark (2007: 182-184) viser, er der visse kontekster hvor $p$-elementet ikke kan udelades. Dette gælder når komplementet til $\mathrm{P}$ betegner en person:

[...] når du nu skal *(hen) til Per og Lis i morgen [...]

(Oprindeligt autentisk eksempel fra Hovmark 2007:

182; tilpasset i Nguyen 2019c: 125)

p-elementet kan heller ikke udelades i følgende sætninger; udeladelsen af $p$-elementet giver et ugrammatisk resultat eller en utilsigtet lokativ betydning:

a. De svømmede *(ind) i fjorden.

b. Vandet løb \#(ud) på gulvet. ${ }^{3}$

c. Købmanden flyttede ??(hen) på hjørnet.

d. Han sneg sig *(ind) på ofret.

e. De sejler ??(rundt) om øen.

((15)a-d er fra Nguyen 2019c: 125, 2020a: 138-140.)

Det at $p$-elementet er obligatorisk, taler for at det er kernen i konstituenten ' $p+\mathrm{PP}$ '. Men der er også mange tilfælde hvor $p$-elementet ikke er obligatorisk, og hvor den translokative betydning er til stede, fx Han løb (ned) $i$ vandet. Det er svært at afgøre om der i sådanne tilfælde er et implicit eller "usynligt" p-element (dvs. et slags nulmorfem), men det kan man antage. I så fald ville strukturen være parallel med fx (14)-

3 Havelågen (\#) angiver at semantikken i et givet eksempel er utilsigtet eller ikke-velformet. I (15)b angiver havelågen at semantikken er utilsigtet hvis $u d$ udelades. 
(15). ${ }^{4}$

For nærværende indtager jeg ikke noget synspunkt mht. om $p$-elementet er usynligt eller slet ikke er til stede i tilfælde som Han løb (ned) $i$ vandet. Jeg diskuterer heller ikke nærmere i hvilke kontekster $p$-elementet er obligatorisk (eller skal være synligt); det er mere kompliceret end som så, se Gehrke (2007) og Harder et al. (1996: 169-171, 189192). Det vigtigste er for nærværende antagelsen om at $p$-elementet er kernen i en konstituent $p$ P, og at $p$-elementet selekterer en PP som sit komplement.

\section{ANALYSEN}

I dette afsnit vil jeg fremlægge min analyse med udgangspunkt i $p$ P-strukturen og med udgangspunkt i de andre antagelser jeg indtil videre har indført. Jeg vil altså bl.a. analysere konstruktionen hvor en NP står foran retningsadverbiet $p$ som i (16) og (17) (gentaget fra (1) og (2)):

a. I dag er Ole Nydahl selv lama med 110 centre jorden rundt.

b. Det var på det tidspunkt længe siden, han havde skrevet digte.

Livet ud bebudede han nye digte, og alle håbede.

c. Dag ud og dag ind vandrede han afsted ad landevejen ...

a. Han kører alle turister det samme sted hen.

b. I 1971 sejlede jeg Australien rundt i en åben 16-fods båd.

(Eksemplerne er fra KorpusDK)

Som nævnt i afsnit 1 kan man måske følge min analyse i Nguyen (2020a,b, 2021a,b) og betragte hele konstruktionen som en postposi-

4 Når der ikke er et (synligt) p-element, er det nogle gange nødvendigt at verbet er trykreduceret for at translokativ betydning kan udtrykkes, jf. forskellen mellem Han ville springe $i$ vandet (med trykreduktion og translokativ betydning) og Han ville 'springe i vandet (uden trykreduktion og uden translokativ betydning). Trykreduktion kunne derfor tænkes at være tæt forbundet med $p$ : Da $p$-elementet udtrykker translokativ betydning, og da trykreduktion er nødvendigt for at udtrykke translokativ betydning, kunne tilstedeværelsen af trykreduktion være lig med tilstedeværelsen af et $p$-element. 
tionalfrase. I denne postpositionalfrase er retningsadverbiet en postposition, og NP'en er postpositionens komplement (og dermed udgår hele $p$ P-strukturen). Postpositionalfrasen ville da se således ud, her eksemplificeret med jorden rundt:

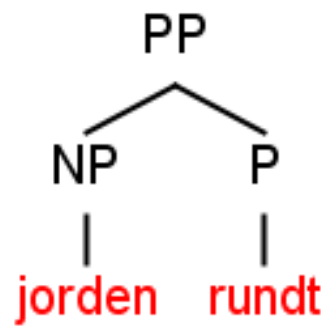

Postpositionsanalysen rejser dog nogle teoretiske problemstillinger. For det første er dansk et sprog der altovervejende har kernen til venstre for sit komplement, $\mathrm{fx}$ VP'en besøge sin ven og AdjP'en stolt af sin ven. Postpositionerne ville være en undtagelse herfra da de per definition er kerner der befinder sig til højre for deres komplement (som i (18) ovenfor). For det andet kan de elementer der siges at være postpositioner, både selektere konstituenter til højre og til venstre. Rundt fx selekterer da enten en PP til højre (som i rundt om Australien) eller en NP til venstre (som i fx Australien rundt).

På dette punkt vil jeg inddrage Ockhams ragekniv, nemlig det videnskabsteoretiske princip om at indføre så få antagelser i sin forklaring som muligt. Antager man at retningsadverbiet kun selekterer en PP til højre, har man færre antagelser end hvis man antager at retningsadverbiet både kan selektere en PP til højre og en NP til venstre (se dog Huddleston \& Pullum 2002: 631-632, 640, som abonnerer på sidstnævnte betragtningsmåde). Jeg vil derfor antage at retningsadverbiet altid er et p-element, og at det kun selekterer en PP til højre, dvs. også i tilfælde som (1)/(16) og (2)/(17), som vist i (7) ovenfor, gentaget her som (19): 


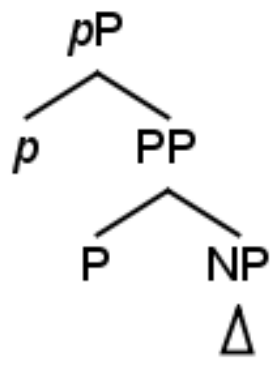

Det er dog væsentligt at bemærke at jeg i det følgende indfører yderligere antagelser i analysen. Antagelserne er dog ikke specielt kontroversielle, men derimod rimeligt veletablerede (måske bortset fra antagelsen i (20)c). Det skyldes at antagelserne også findes i andre analyser, eller at de bygger på de samme principper som man finder i andre analyser (se fodnote 4-7 nedenfor). Antagelserne giver desuden nogle forudsigelser som man kan teste, og derfor kan man i princippet falsificere antagelserne. Denne testbarhed vil jeg gøre brug af.

De antagelser jeg yderligere vil indføre, er som følger:

a. P kan være implicit eller "usynligt" (dvs. det er et slags nulmorfem). ${ }^{5}$

b. Usynligt P kan ikke tilskrive kasus. ${ }^{6}$

c. Komplementet til usynligt P flytter til venstre for $p$-elementet, nærmere bestemt til $p \mathrm{P}$-spec (og dermed opstår konstruktioner som Australien rundt). ${ }^{7}$

d. Flytningen af komplementet er forårsaget af mangel på kasus. ${ }^{8}$

5 Det er en udbredt antagelse at der findes usynlige elementer. Et eksempel herpå er nulmorfemet for pluralis (et år, fere år-Ø) (Togeby 2003: 21); se andre eksempler i bl.a. Hansen \& Heltoft (2011: 663-666). Hvad angår usynlige P'er mere specifikt, så antages de også at være til stede i fx A. Kobayashi (2014) og McCawley (1988).

6 Også Kayne (1984: 195) antager at usynlige P'er ikke kan tilskrive kasus. Derudover antages det at synlige P'er i visse kontekster heller ikke kan tilskrive kasus (se fx Law 1998: 231-232, 2006: 658-661).

7 Se lignende antagelser i Matsumoto (2013) og Matsubara (2012: 501-502); se også fodnote 9 nedenfor.

8 Det er en almen antagelse at flytninger er forårsaget af noget, herunder kasus, se fx Baltin (2001). Dette er fx tilfældet i passiv, hvor komplementet til V flytter til subjektspositionen for at få tilskrevet kasus:

(i) I går blev Francis forfremmet 
Hvad usynligt $\mathrm{P}$ angår, så er det svært at sige hvad det generelt udtrykker; man er nødt til at se på de enkelte tilfælde. Ved fx hen betyder det usynlige P (næsten) det samme som til ( $\mathrm{fx}$ et andet sted hen), og ved rundt betyder det nogle gange det samme som om ( $\mathrm{fx}$ Vi sejlede Australien rundt). Derudover kan det som sagt antages at det i nogle tilfælde bidrager med en semantik der udtrykker udstrækning (se (1)/ (16), og se Nguyen 2020a: 36-76, 262-274, 2020b: 98-101, A. Kobayashi 2014: 18-19).

Både synligt og usynligt P spiller en rolle i for om NP'en får tilskrevet kasus. Som nævnt i afsnit 2.2 er det en standardantagelse at en NP får tilskrevet kasus fra en kerne når NP'en enten står i komplementpositionen til denne kerne eller i specifikatorpositionen til denne kerne. Det blev også nævnt at en NP skal have én og kun én kasus; ellers giver det et ugrammatisk resultat. Den mere konkrete applicering af disse antagelser på NP’en i $p$ P er som følger:

(21) Hvordan NP'en får tilskrevet kasus af $\mathrm{P}$ og $p$-elementet

a. NP'en får tilskrevet kasus af et synligt $\mathrm{P}$ når NP'en står i komplementpositionen til dette synlige $\mathrm{P}$.

b. NP'en får tilskrevet kasus af $p$-elementet når NP'en står i $p \mathrm{P}$ spec.

(22) Ugrammatikalitet: Hvordan NP'en får for meget eller for lidt kasus

a. Hvis NP'en får kasus fra både $\mathrm{P}$ og $p$-elementet, giver det et ugrammatisk resultat.

b. Hvis NP'en hverken får kasus fra P eller $p$-elementet, giver det et ugrammatisk resultat.

I de næste to afsnit vil jeg med alle antagelserne in mente vise hvordan analysen forudsiger hvilke NP-placeringer der er mulige og umulige, dvs. hvornår NP'en skal og ikke skal være foranstillet. I afsnit 3.1 gennemgår jeg konstruktionerne med rundt, ud og ind. I afsnit 3.2 fortsætter jeg med gennemgangen af konstruktionerne med hen: Disse er mere komplicerede fordi de typisk involverer sted-NP'er, som opfører sig særegent. 
3.1 Konstruktioner med rundt, ud og ind

Jeg vil tage udgangspunkt i rundt, som nok er det p-element der kan forekomme med flest forskellige slags foranstillede NP'er (Nguyen 2020a: 70-72, 2020b: 100-101). Se følgende eksempler, hvor NP'en Australien både kan stå før $p$-elementet og efter $p$-elementet (med et synligt P):

a. I 1971 sejlede jeg Australien rundt i en åben 16-fods båd.

b. I 1971 sejlede jeg rundt om Australien i en åben 16-fods båd.

$$
((23) \mathrm{a}=(2) \mathrm{b} /(17) \mathrm{b})
$$

Analysen af disse to konstruktioner kan ses nedenfor ( $t$ står for trace, dvs. et 'spor', som markerer den position som et element flytter fra):
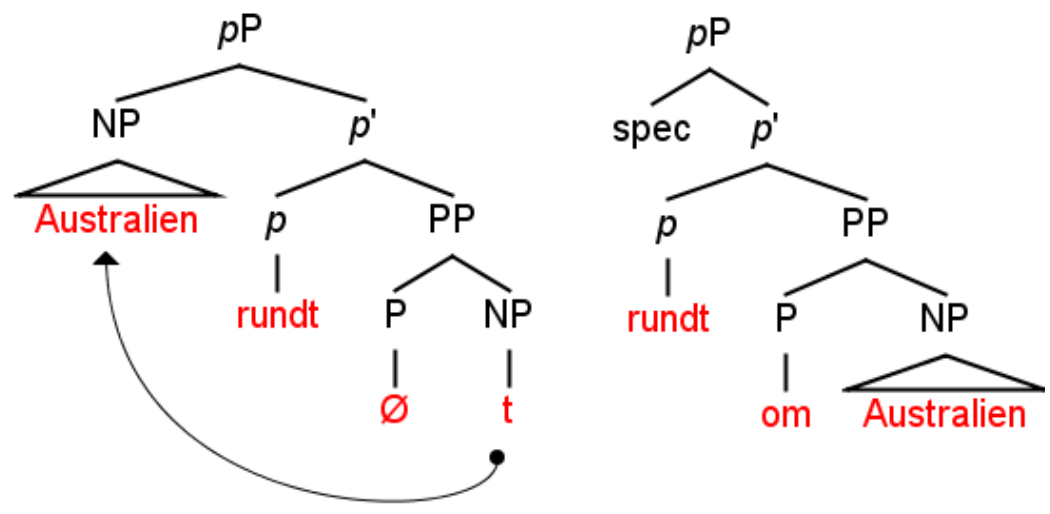
I (24) selekterer $p$-elementet rundt en PP med et usynligt P og NP'en Australien, som er komplementet til det usynlige $\mathrm{P}$, flytter til venstre for rundt, nemlig til $p$ P-spec.' 'NP'en kan i komplementpositionen til usynligt $\mathrm{P}$ ikke få tilskrevet kasus fordi usynligt $\mathrm{P}$ ikke kan tilskrive kasus (se antagelsen i (20)b). Derfor flytter NP'en fra komplementpositionen til $p \mathrm{P}$-spec og får tilskrevet kasus af $p$-elementet (se antagelsen i (21)b). NP'en har dermed én kasus, og det giver derfor et grammatisk resultat.

I (25) er P derimod synligt, og NP'en flytter ikke. NP'en får i komplementpositionen tilskrevet kasus af synligt $\mathrm{P}$ (se antagelsen i (21)a), og NP'en flytter derfor ikke til $p$ P-spec for at få tilskrevet kasus.

NP'en har dermed én kasus, og det giver derfor et grammatisk resultat. Spørgsmålet er nu hvorfor de følgende konstruktioner er ugrammatiske:

a. $\quad$ *I 1971 sejlede jeg rundt Australien i en åben 16-fods båd.

b. $\quad{ }^{*}$ I 1971 sejlede jeg Australien rundt om i en åben 16-fods båd. Se de relevante træstrukturer overfor:

9 Bemærk at der er god grund til at tro at NP'en flytter til en position indenfor $p$ P-konstituenten. 'NP + p' kan nemlig både flytte samlet og sideordnes (begge dele er almindelige konstituenttests):

(i) Og Australien rundt ville han sejle, også selvom han ikke havde en klink på lommen.

(Konstrueret eksempel)

(ii) Flere krydstogter i Australien og jorden rundt gør holdt i Melbourne.

(https://krydstogtcenter.dk/destinationer/australien-og-new-zealand/melbourne/) 

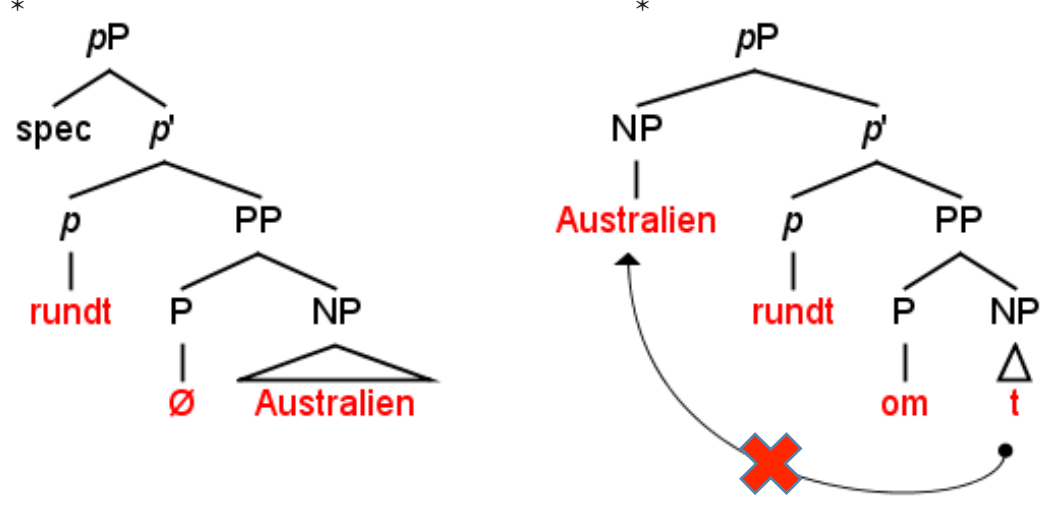

Min analyse forudsiger at konstruktionerne er ugrammatiske. I (27) er $\mathrm{P}$ usynligt, og NP'en får derfor ikke tilskrevet kasus af $\mathrm{P}$ (usynligt $\mathrm{P}$ tilskriver ikke kasus). NP'en får heller ikke tilskrevet kasus af $p$-elementet fordi NP'en ikke er flyttet til $p$ P-spec. NP'en får dermed ikke tilskrevet nogen kasus, og konstruktionen er derfor ugrammatisk (se antagelsen i (22)b).

I (28) er P synligt, og NP'en får tilskrevet kasus af P inden NP'en flytter til $p \mathrm{P}$-spec, hvor den ligeledes får tilskrevet kasus, nemlig fra $p$-elementet. NP'en får dermed tilskrevet to kasus, en fra $\mathrm{P}$ og en fra p-elementet. Analysen forudsiger derfor at konstruktionen i (28) er ugrammatisk; en NP skal have én og kun én kasus (jf. kasusfiltret i afsnit 2.2 og antagelsen i (22)a). Forudsigelserne stemmer altså overens med data.

Ovenfor har jeg diskuteret rundtsom $p$-element, men analysen kan også overføres til $u d$ og ind. Disse $p$-elementer kan, ligesom rundt, også tage en PP, fx Han gik udpå verandaen/ind i butikken. Analysen kan på samme måde redegøre for kontrasterne mellem (u)synligt P og (ikke-)flytning af NP. Når P er usynligt, skal NP'en flytte til $p$ P-spec for at få kasus (16)b/(29)a. Hvis NP'en ikke flytter til $p \mathrm{P}$-spec, făr den ikke tilskrevet nogen kasus, og resultatet bliver derfor ugrammatisk (29)b: 
a. Det var på det tidspunkt længe siden, han havde skrevet digte. Livet ud bebudede han nye digte, og alle håbede.

b. $\quad *$... Ud livet bebudede han nye digte, og alle håbede.

Når P er synligt, skal NP'en ikke flytte til $p \mathrm{P}$-spec, men forblive i sin position, hvor den fär tilskrevet kasus af $\mathrm{P}$, se (3)d/(30)a. Hvis NP'en flytter til $p \mathrm{P}$-spec, giver det et ugrammatisk resultat fordi NP'en i så fald vil få tilskrevet to kasus, se (4)d/(30)b:

a. Han sprang ud i livet med stor begejstring.

b. $\quad{ }^{*}$ Han sprang livet ud i med stor begejstring.

Jeg er klar over at livet ud og ud i livet i hhv. (29)a og (30)a langtfra er synonyme. Ikke desto mindre er begge konstruktioner i princippet strukturelt velformede. Det er derfor nærliggende at antage at der er en strukturel parallelitet mellem de to konstruktioner, på samme måde som der er en strukturel parallelitet mellem Australien rundt og rundt om Australien. Jeg foreslår altså at konstruktioner med ud (og ind) kan analyseres på samme måde som rundt - dvs. at NP'ens position ved $u d$ (og ind) ligeledes afhænger af om kasus tilskrives af synligt $\mathrm{P}$ eller af p-elementet.

I dette afsnit har jeg fremlagt en analyse af en række konstruktioner hvor NP'en er foranstillet og ikke foranstillet. NP'ens position afhænger af om P er synligt eller ej: Når P er synligt, kan det tilskrive kasus til NP'en, og NP'en forbliver i komplementpositionen; når P er usynligt, kan det ikke tilskrive kasus til NP'en, og derfor skal NP'en flytte til $p$ Pspec for at få tilskrevet kasus af $p$-elementet.

\subsection{Konstruktioner med hen}

Indtil videre har jeg behandlet $p$-elementerne rundt, $u d$ og ind; i dette afsnit behandler jeg $p$-elementet hen. Hen-konstruktioner er mere komplicerede: De involverer stort set kun sted-NP'er, som har en særegen opførsel (se også Nguyen 2018, 2020b: 91-98, 2021a,b og Nguyen \& Østergaard 2019). Umiddelbart ser det ud til at den fremlagte analyse 
kan anvendes på hen. Ligesom andre p-elementer selekterer hen en PP, se (31), og ligesom ved $p$-elementerne rundt, $u d$ og ind skal NP'en (her en sted-NP) flytte til $p$ P-spec hvis P er usynligt, se (32), og forblive i sin position hvis $\mathrm{P}$ er synligt, se (33):

(31) De kørte ${ }_{\mathrm{pP}}$ hen $\left[_{\mathrm{PP}}\right.$ i butikken]].
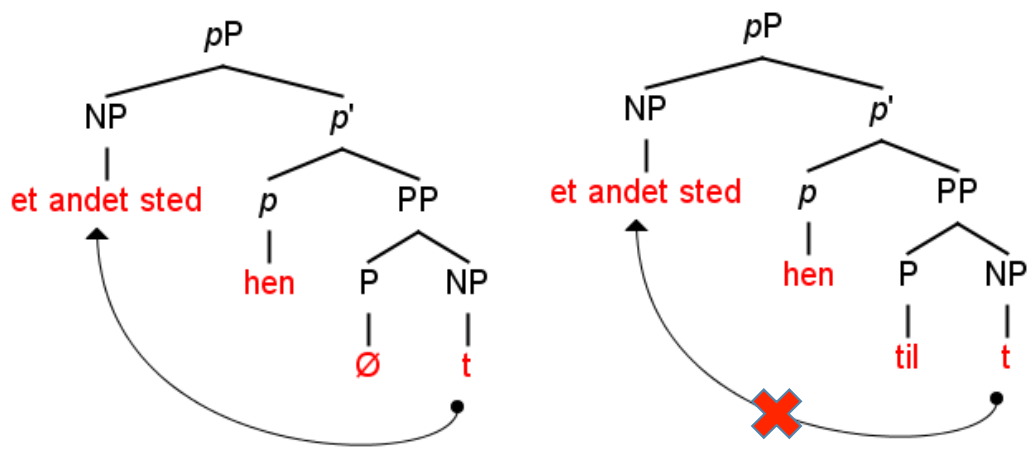

I (32) er P usynligt og kan derfor ikke tilskrive kasus til sted-NP'en; sted-NP'en flytter til $p \mathrm{P}$-spec og får tilskrevet kasus af $p$-elementet. I (33) er P synligt, og sted-NP'en får tilskrevet kasus af P. Da sted-NP'en flytter til $p$ P-spec, får den også kasus tilskrevet af $p$-elementet. Det giver et ugrammatisk resultat fordi en NP skal have én og kun én kasus.

Men følgende data er problematiske for den fremlagte analyse. StedNP'en kan stå til højre for både hen og for andre $p$-elementer, også selvom der ikke er noget synligt $\mathrm{P}$, se (34).

(34) Når stykket blev kedeligt eller sørgeligt, gik publikum hen/ind/ ud ... et andet sted, hvor der blev spillet operetter.

(Tilpasset eksempel fra Nguyen 2020a: 275, oprindeligt konstrueret ud fra et KorpusDK-eksempel)

Man kan forsøge at forklare (34) ved at sige at p-elementet og stedNP'en er to selvstændige konstituenter. Hvis det er tilfældet, er sted- 
NP'en ikke inde i $p$ P. Men der er evidens for at sted-NP'en danner en konstituent med $p$; dette kan ses ved at ' $p+$ NP' kan sideordnes som vist i (35) (se også Nguyen 2020a: 274-276, 293, 2020b: 104):

(35) Busturen ind til byen og ud et andet sted var hundedyr.

Spørgsmålet er hvorfor sted-NP'en kan være højrestillet ved hen og andre $p$-elementer når $\mathrm{P}$ er usynligt, som i (34) og (35). Denne konstruktion burde, ifølge den analyse jeg har opstillet, være ugrammatisk da usynligt P ikke kan tilskrive kasus. Svaret ligger muligvis i selve stedNP'en. Det kan observeres at adverbielle sted-NP'er ikke nødvendigvis behøver at forekomme med P, i modsætning til almindelige NP'er (se Nguyen 2018, 2020b: 91-98, 2021a: 226, 2021b: 418 og Nguyen \& Østergaard 2019): ${ }^{10}$

(36) Sted-NP: P er optionelt.

a. Han kan sælge bøgerne et andet sted.

b. Han kan sælge bøgerne på et andet sted.

(37) Almindelig NP: P er obligatorisk.

a. Han kan sælge bøgerne i en anden butik.

b. $\quad *$ Han kan sælge bøgerne en anden butik.

Man kan altså fortolke dataene i (36) som om sted-NP'er ikke altid behøver at få tilskrevet kasus (for mere diskussion, se Nguyen 2018 og Nguyen \& Østergaard 2019, og også Barrie \& Yoo 2016, Collins 2007, Larson 1985, Taraldsen 2017 og A. Kobayashi 2014). På samme måde kan man betragte dataene i (34) og (35): Sted-NP'er behøver hverken at få tilskrevet kasus af $p$-elementet eller af P. Se træstrukturen overfor:

10 Adverbielle temporale NP'er og mådes-NP'er kan dog godt forekomme uden P (se fx Aa. Hansen 1967: 223-226, 349, K. Kobayashi 1999, Larson 1985 og McCawley 1988):

(i) De skulle have mødt hende sidste uge.

(ii) En god måde at vinde en masse vælgere. 
(38) Sted-NP'en (eksemplificeret med et andet sted) får hverken kasus fra $p$-elementet eller fra P.

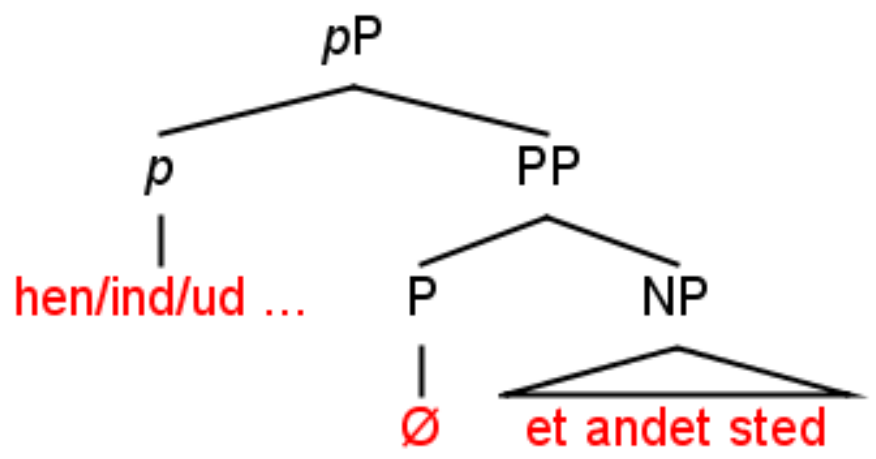

Vi har nu to situationer: En situation hvor sted-NP'en får tilskrevet kasus af $p$-elementet eller af $\mathrm{P}$, og en situation hvor sted-NP'en hverken får tilskrevet kasus af $p$-elementet eller af P. Hvad angår det sidstnævnte tilfælde, stipulerer jeg på baggrund af eksempler som (36) at sted-NP'er optionelt kan tilskrive sig selv kasus. Det betyder at sted-NP'er ikke altid har brug for at få tilskrevet kasus et andet sted fra (se særligt Larson 1985: 605 ff.). Med andre ord: Den kasus som sted-NP'er tilskriver sig selv, kan slås til og fra. Det er dog utilfredsstillende at indføre denne optionalitet - analysen bliver sværere at falsificere.

Analysen forudsiger dog ganske korrekt at sted-NP'en ikke kan være foranstillet når $\mathrm{P}$ er synligt, $\mathrm{fx}{ }^{*} V i$ kører et andet sted ned til; se også (33). Uanset om sted-NP'en har kasus i forvejen, forudsiger analysen at NP'en ikke kan være foranstillet fordi den både får tilskrevet kasus af $p$-elementet og af P. Men når NP'en ikke er foranstillet, $\mathrm{fx}$ i ned til et andet sted, er jeg nødt til at stipulere at sted-NP'en ikke har tilskrevet sig selv kasus.

Det særlige ved sted-NP'er er altså at de kan tilskrive sig selv kasus. Hvis der i stedet er tale om almindelige NP'er, følger det af analysen at sådanne NP'er ikke kan være højrestillede (Nguyen 2020a: 275-276): 
*Når stykket blev kedeligt eller sørgeligt, gik publikum hen/ ind/op en anden sal [...].

(Tilpasset fra Nguyen 2020a: 275)

Da almindelige NP'er ikke kan tilskrive sig selv kasus, og da usynligt $\mathrm{P}$ ikke kan tilskrive kasus, er eksempler som (39) ugrammatiske: NP'en får ikke tilskrevet nogen kasus, og det fører til en ugrammatisk konstruktion (dette forklarer dog ikke hvorfor NP'en ikke kan stå i $p$ P-spec

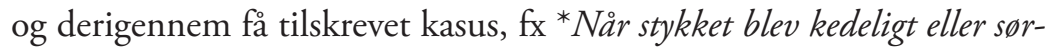
geligt, gik publikum en anden sal hen/ind/ud; se afsnit 4.1.).

Den analyse jeg har fremlagt for rundt, $u d$ og ind, kan altså overføres til hen-konstruktioner med sted-NP'en, også selvom man yderligere skal antage at sted-NP'er nogle gange tilskriver sig selv kasus. Denne antagelse må diskuteres andetsteds og forhåbentlig kunne understøttes af mere evidens end eksempler som (36).

\subsection{Resume af afsnit 3}

I dette afsnit har jeg fremlagt en generativ analyse af konstruktionerne hvor NP'en står til venstre for $\mathrm{p}$ (dvs. i $p \mathrm{P}$-spec) og til højre for $\mathrm{p}$ (dvs. i komplementpositionen til P). NP'en flytter til $p$ P-spec afhængig af om P er synligt eller "usynligt", dvs. om P er realiseret som en rigtig præposition eller som et slags nulmorfem. Hvis P er synligt, kan NP'en ikke flytte til $p$ P-spec ( ${ }^{*}$ Australien rundt om vs. rundt om Australien). Hvis P er usynligt, kan NP'en ikke forblive på sin position (*rundt Australien vs. Australien rundt). Dette kan opsummeres i følgende træstrukturer ('xyz' står for synligt sprogligt materiale): 
(40) Fx Australien rundt

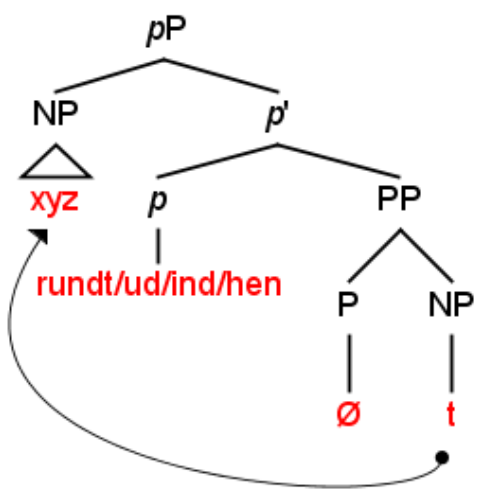

(42) $\mathrm{Fx}^{*}$ Australien rundt om

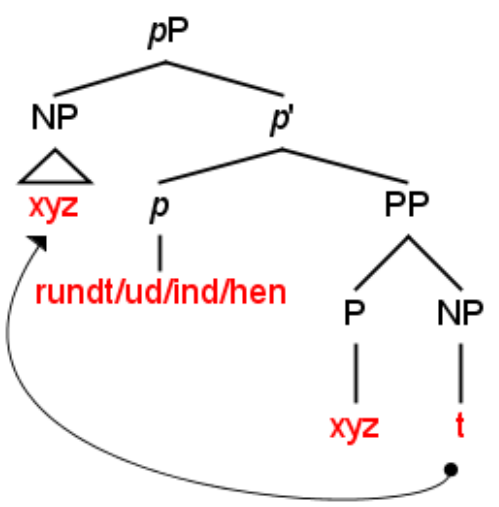

(41) Fx rundt om Australien

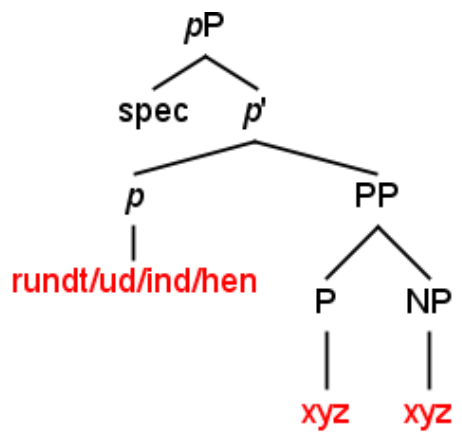

(43) Fx * rundt om Australien

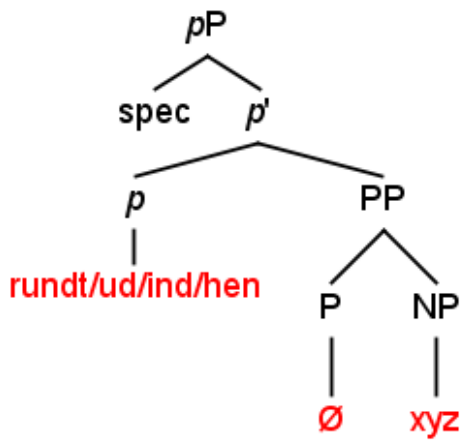


Jeg har foreslået at (u)synligt P og (ikke-)flytning af NP har noget med kasus at gøre. Synligt P tilskriver kasus til NP'en, og NP'en kan derfor ikke flytte til $p$ P-spec for at fă kasus. Usynligt $\mathrm{P}$ tilskriver ikke kasus til NP, og NP'en skal derfor flytte til $p$ P-spec for at få tilskrevet kasus af $p$-elementet. Analysen forudsiger at de tilfælde hvor NP'en får for meget kasus (mere end én) eller slet ikke får kasus, er ugrammatiske, se (42) og (43).

Det er værd at bemærke at min analyse er forenelig med argumenterne for at der rent faktisk er tale om at $p$-elementet er en postposition når NP'en er foranstillet $p$-elementet (se argumenterne i Nguyen 2019b, 2020a,b, og se også Nguyen 2021a,b). Hvis man udelukkende beskæftiger sig med den streng man rent faktisk kan se, dvs. en NP og et $p$-element, og ikke antager at der er en PP med et usynligt $\mathrm{P}$, så vil man stadig kunne betragte $p$-elementet som en postposition, men det er som sagt heller ikke helt uproblematisk.

I dette afsnit har jeg fremlagt min analyse og de data den kan forklare. Analysen skaber en sammenhæng mellem NP'ens position til venstre for $p$-elementet og til højre for $p$-elementet og for et synligt P. Indtil nu har forskningslitteraturen ikke i tilstrækkelig grad været opmærksom på at NP'en kan stå på to forskellige positioner; jeg har her taget dette empiriske faktum i betragtning og formuleret en analyse der redegør for hvornår NP’en kan stå på hvilken position. Der er dog også en række problemer og udestående spørgsmål ved analysen. Det handler det næste afsnit om.

\section{PROBLEMER OG UDESTÅENDE SPØRGSMÅL}

Der er mange problemer og udestående spørgsmål ved analysen. Jeg vil her diskutere nogle udvalgte problemer og spørgsmål. De berører de følgende emner:

- konstruktioner hvis ugrammatikalitet er uafhængig af kasus (afsnit 4.1)

- det direkte objekts placering (afsnit 4.2). 
4.1 Konstruktioner hvis ugrammatikalitet er uafhengig af kasus

I det foregående har kasus spillet en hovedrolle for om de givne konstruktioner er grammatiske. I dette afsnit vil jeg kort berøre konstruktioner hvis ugrammatikalitet er uafhængig af kasus. Det drejer sig hovedsageligt om to typer konstruktioner: (i) konstruktioner hvor NP'en ikke kan stå til højre for synligt P, og (ii) konstruktioner hvor NP'en ikke kan stå i $p \mathrm{P}$-spec når $\mathrm{P}$ er usynligt. Et eksempel på førstnævnte konstruktion ses nedenfor:

*Tænderne skal holde ud af livet.

I den analyse jeg har fremlagt, får NP'en livet tilskrevet en kasus af synligt $\mathrm{P}$ af. NP'en har én og kun en kasus. Konstruktionen burde derfor være grammatisk, men det er den ikke. Det har jeg ingen forklaring på, men det kan have noget med semantikken at gøre, altså at der ikke er semantisk ækvivalens mellem (44) og Tanderne skal holde livet ud (som er et KorpusDK-eksempel).

I den anden konstruktionstype hvis ugrammatikalitet er uafhængig af kasus, kan NP'en ikke stå i $p \mathrm{P}$-spec når $\mathrm{P}$ er usynligt. Hvilken slags NP'er der kan forekomme i $p$ P-spec, afhænger af hvilke $p$-elementer der er tale om. Nogle $p$-elementer, fx rundt, tillader mange forskellige NP'er i $p$ P-spec, mens andre $p$-elementer tillader ganske få slags NP'er i $p$ P-spec, fx ind i den idiomatiske konstruktion år ud og år ind (se flere detaljer i Nguyen 2020a: kap 2, 2020b). Endelig er der p-elementer der ikke tillader nogen NP'er i $p$ P-spec, fx frem $\mathrm{i}^{*}$ Han gik kassen frem $\mathrm{i}$ stedet for Han gik frem til kassen. Eksemplerne nedenfor viser at nogle NP'er ikke kan stå i $p$ P-spec, på trods af at andre NP'er godt kan (se afsnit 3.1-3.2):

a. ${ }^{*}$ Han gik stuen ud.

b. ${ }^{*}$ Han gik en anden butik hen.

c. $\quad *$ Han gik et andet sted ind. 
Selv hvis min analyse er rigtig, kan den ikke forklare sådanne tilfælde. Ugrammatikaliteten har ikke noget med kasus at gøre. For nærværende har jeg ingen forklaring på hvorfor nogle NP'er ikke kan stå i pP-spec, hvorimod andre NP'er kan.

Det er dog muligt at sige lidt mere om eksemplet med sted-NP nedenfor:

(46) *Han gik hen stedet.

Sted-NP'en indeholder den efterstillede artikel. Det er en interessant observation at sted-NP'er med efterstillet artikel ikke kan fungere som adverbialer uden P, fx De mødtes* ( $p a ̊)$ stedet (se mere i Nguyen 2018, 2020a: 41-63, 274-276, 2020b : 92-98, 2021a: 233-235, 2021b: 421422 og Nguyen \& Østergaard 2019). Denne observation kan tolkes sådan at sted-NP'er med efterstillet artikel (af en eller anden grund) ikke kan tilskrive sig selv kasus. Hvis det er rigtigt, følger det af min analyse at (46) er ugrammatisk: Sted-NP'en med den efterstillede artikel kan ikke tilskrive sig selv kasus, og usynligt P kan ikke tilskrive kasus til sted-NP'en. Sted-NP'en har dermed ingen kasus, og konstruktionen er derfor ugrammatisk, se (47):

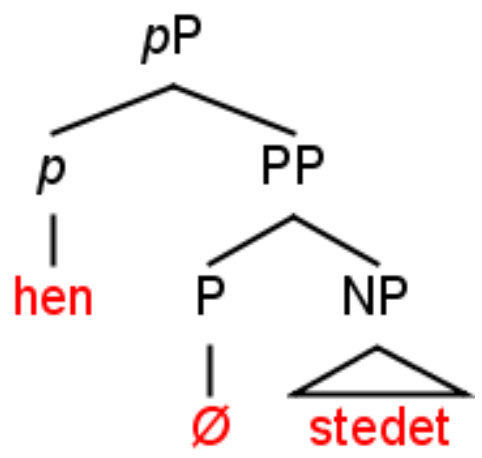


Men nedenstående eksempel er et problem for denne idé:

${ }^{*}$ Han gik stedet hen.

Selv hvis det skulle være rigtigt at en sted-NP med efterstillet artikel har en manglende evne til at tilskrive sig selv kasus, forklarer dette ikke hvorfor denne slags sted-NP ikke kan få kasus i pP-spec. Jeg har ingen forklaring på hvorfor nogle sted-NP'er kan flytte til $p$ P-spec, hvorimod andre sted-NP'er ikke kan. Det ser ud til at de sted-NP'er der har evnen til at tilskrive sig selv kasus, også kan få tilskrevet kasus i $p \mathrm{P}$-spec. Man kan også formulere det på følgende måde: Hvis en sted-NP har evnen til at fungere som adverbial uden $\mathrm{P}$, så kan den også stå i $p \mathrm{P}-$ spec og få tilskrevet kasus derigennem. Hvorfor der skulle være denne forbindelse, står mig ikke helt klart.

I dette afsnit har jeg diskuteret konstruktioner hvis ugrammatikalitet ser ud til at være uafhængig af kasustilskrivning. Det drejer sig hovedsageligt om (i) konstruktioner hvor NP'en ikke kan stå til højre for synligt $\mathrm{P}$, og (ii) konstruktioner hvor NP'en ikke kan stå i $p \mathrm{P}$-spec når $\mathrm{P}$ er usynligt. Det er et åbent spørgsmål om analysen kan modificeres så den også kan gøre rede for disse konstruktioner.

\subsection{Det direkte objekts placering}

Et andet udestående spørgsmål er hvor det direkte objekt befinder sig når det forekommer i tæt forbindelse med en $p$ P. Det har jeg i analysen ikke taget stilling til. Umiddelbart peger dataene i to forskellige retninger. 'Direkte objekt $+p+$ PP' kan sideordnes, hvilket kunne tyde på at 'direkte objekt $+p+\mathrm{PP}$ ' udgør en konstituent, nemlig en $p \mathrm{P}$ :

(49) Vi ville køre $\left[_{p \mathrm{P}}\right.$ Ole hjem til hans forældre $]$ og $\left[_{p \mathrm{P}}\right.$ Peter ind til byen]. 
(50) Vi ville køre $\left[_{p \mathrm{P}}\right.$ Ole hjem til hans forældre $]$ og $\left[_{p \mathrm{P}}\right.$ Peter et andet sted hen]. ${ }^{11}$

Derimod kunne følgende to observationer tyde på at det direkte objekt ikke er inde i $p \mathrm{P}$ 'en. Den første observation er at et tids- og mådesadverbial kan stå mellem det direkte objekt og $p$-elementet (Heltoft 1992: 32-35, Jørgensen 2014: 98-99), se (51):

Vi ville køre Peter to gange/hurtigt ind til byen.

Hvis tids- og mådesadverbialet står udenfor $p$ P'en, må det direkte objekt nødvendigvis også stå udenfor $p$ P'en.

Den anden observation er at 'direkte objekt $+p+$ PP' ikke kan flytte, se (52):

* Det var [Peter ind til bageren] vi kørte $t$.

Ud fra denne anden observation kan man dog ikke med sikkerhed sige noget om hvorvidt 'direkte objekt $+p+$ PP' er en konstituent. Der findes konstituenter som ikke kan flytte. Dette gælder fx subjektet i at-sætninger, ${ }^{*} H v i l k e n$ butik tror du at er lukket? Blot fordi subjektet ikke kan flytte, betyder det ikke at subjektet ikke er en konstituent. Ud fra (52) kan man dog sige at flytningstesten ikke viser at der er tale om en konstituent.

Hvor det direkte objekt befinder sig, er altså et vanskeligt spørgsmål. Uanset om det direkte objekt er inde i pP (se fx Den Dikken 1995, Kayne 1985, Svenonius 2003, 2007, Vikner 2016: 237 ff., 2017: 376 ff. og Wurmbrand 1998, 2000), eller ikke er (se fx Dehé 2002: kap. 5, Farrell 2005 og Johnson 1991: 590-608), så skal en fremtidig analyse forholde sig til hvor både det direkte objekt og den foranstillede NP står, fx i Vi sejlede Peter øen rundt eller Vi sejlede Peter et andet sted hen.

11 Den anonyme fagfællebedømmer peger på et potentielt problem ved dette argument. Se det følgende eksempel:

(i) Vi ville køre [Ole hjem om morgenen] og [Peter ind om aftenen].

Hvis de kantede parenteser omkranser $p$ P'er, så skal man antage at PP'erne om morgenen og om aftenen befinder sig i $p$ P'erne. Denne antagelse er måske problematisk. 
Hidtil har man ikke været særlig opmærksom på at der kan stå en NP direkte til venstre for $p$-elementet - en NP som ikke er det direkte objekt.

\section{SAMMENFATNING OG PERSPEKTIVER}

I denne artikel har jeg fremlagt en generativ analyse af konstruktioner hvor en NP står foran et retningsadverbium, fx Australien rundt, og sammenlignet dem med konstruktioner hvor NP'en står efter retningsadverbiet og en præposition, fx rundt om Australien. Tidligere forskningslitteratur har ikke været særligt opmærksom på at NP'en kan stå på disse to positioner. Jeg forsøger at råde bod på dette ved at formulere en analyse der skal redegøre for hvornår NP'en kan stå på den ene og den anden position.

I afsnit 2 blev det fundament som analysen bygger på, fremlagt. Analysen bygger på (i) generative standardantagelser, herunder hvordan frasestrukturer ser ud, og hvordan NP'er tilskrives kasus af en kerne, og på (ii) en $p$ P-konstituent hvor retningsadverbiet $p$ er kerne og selekterer en PP, fx i ind i butikken.

I afsnit 3 fremlægges selve analysen. Når NP'en er foranstillet, $\mathrm{fx}_{\mathrm{x}}$ Australien rundt, selekterer $p$-elementet en PP med et implicit eller "usynligt" P (dvs. et slags nulmorfem). NP'en flytter til $p$ P-spec for at få tilskrevet kasus af $p$-elementet fordi usynligt $\mathrm{P}$ ikke kan tilskrive kasus. Analysen forudsiger desuden at konstruktioner som *Australien rundt om og * rundt Australien er ugrammatiske: Førstnævnte er ugrammatisk fordi NP'en får tilskrevet kasus af både synligt P om og af $p$-elementet rundt, og sidstnævnte er ugrammatisk fordi NP'en ikke får tilskrevet nogen kasus (en NP skal altid have én og kun én kasus).

Da der er en række problemer og udestående spørgsmål som den fremlagte analyse hverken løser eller besvarer, blev disse diskuteret i afsnit 4. Disse problemer og udestående spørgsmål angår først og fremmest en række konstruktioner hvis ugrammatikalitet ikke umiddelbart kan forklares med kasus. Problemerne og spørgsmålene angår desuden det direkte objekts placering når det direkte objekt forekommer i tæt forbindelse med en $p$ P. Her er det ikke umiddelbart klart om det direkte objekt befinder sig inde i $p$ P'en, eller om det befinder sig udenfor $p$ P'en. Det er oplagt at disse problemer og spørgsmål diskuteres i videre undersøgelser. 
Derudover ville det nok være oplagt at undersøge om nogle af de mange antagelser i analysen (især dem i (20)-(22)) kan understøttes af yderligere uafhængig evidens; dette vil styrke analysen betragteligt. Hertil kommer at det vil være interessant at se i hvor høj grad den fremlagte analyse er anvendelig på konstruktioner af typen landet over, vinteren igennem og et andet sted fra. De to førstnævnte konstruktionstyper minder om rundt-, ud- og ind-konstruktioner ved at have en udstrækningssemantik, og interessant nok kan over og igennem nogle gange erstattes med $p$-elementerne rundt og $u d$, fx landet rundt og vinteren $u d$. Konstruktionstypen med fra minder semantisk og syntaktisk om hen-konstruktioner ved også at have en foranstillet sted-NP. Alle disse problemer og spørgsmål er komplicerede, og behandlingen af dem må derfor udskydes til fremtidig forskning.

\section{TAK}

Denne artikel bygger primært på kapitel 5 i min ph.d.-afhandling (Nguyen 2020a). Jeg vil gerne takke Kasper Boye, Henrik Jørgensen, Paul Law og Sten Vikner, som alle på en eller anden måde har bidraget til artiklen: enten i form af kommentarer til kapitlet i afhandlingen eller i form af kommentarer til ph.d.-forsvaret. En stor tak skylder jeg redaktørerne Ken Ramshøj Christensen og Jan Heegård Petersen, som har givet værdifuld feedback, kommentarer og opmuntring. Eventuelle fejl og mangler tager jeg på min kappe.

Michael Nguyen

Dansk Sprognævn

mn@dsn.dk

\section{LITTERATUR}

Allan, R., P. Holmes \& T. Lundskær-Nielsen. 1995. Danish: A comprehensive grammar. London: Routledge Taylor \& Francis Group.

Asbury, A., B. Gehrke \& V. Hegedűs. 2006. One size fits all: prefixes, particles, adpositions and cases as members of the category P.C. Keskin (red.), UiL OTS Yearbook 2006, 1-17. Utrecht: Utrecht Institute of Linguistics.

Ayano, S. 2001. The layered internal structure and the external syntax of PP. Ph.d.-afhandling. Durham University. 
Baker, M. 2013. Agreement and case. M. Den Dikken (red.), The Cambridge handbook of generative syntax, 607-654. Cambridge University Press.

Baltin, M.R. 2001. A-movements. M.R. Baltin \& C. Collins (red.), The handbook of contemporary syntactic theory. 266-254 Malden, MA: Blackwell Publishers. DOI: $10.1002 / 9780470756416$.

Barrie, M \& I.W.H. Yoo. 2017. Bare nominal adjuncts. Linguistic Inquiry 48. 499512. DOI: 10.1162/ling_a_00251.

Bassehansen.dk. u.å. http://bassehansen.dk/wp-content/uploads/2017/06/ERINDRINGER.pdf (tilgået 14. april 2021).

Becker-Christensen, C. 2010. Dansk syntaks. Frederiksberg: Samfundslitteratur.

Bjerre, T. 2003. Locative prepositions and adverbs in Danish. Nordlyd 31(1). 1-12.

Chomsky, N. 1981. Lectures on Government and Binding. The Pisa lectures. Dordrecht: Foris.

Christensen, R.Z. \& L. Christensen. 2014 [2005]. Dansk grammatik. 3. udg. Odense: Syddansk Universitetsforlag.

Collins, C. 2007. Home sweet home. NYU Working Papers in Linguistics 1. 1-34.

DDO (Den Danske Ordbog). u.å. http://ordnet.dk/ (tilgået 7. juli 2021).

Dehé, N. 2002. Particle verbs in English. Syntax, information structure and intonation. Philadelphia: John Benjamins. DOI: 10.1075/la.59.

Den Dikken, M. 1995. Particles: On the syntax of verb-particle, triadic, and causative constructions. New York: Oxford University Press.

Diderichsen, P. 1976 [1946]. Elementer dansk grammatik. Genoptryk af 3. udg. København: Gyldendal.

Falk, H. \& A. Torp. 1900. Dansk-norskens syntax i historisk fremstilling. Kristiania: H. Aschehoug.

Farrell P. 2005. English verb-preposition constructions: Constituency and order. Language 81(1). 96-137. DOI: 10.1353/lan.2005.0017.

Gehrke, B. 2007. Putting path in place. L. McNally \& E. Puig-Waldmüller (red.), Proceedings of Sinn und Bedeutung 11, 244-260.

Hansen, E. 2006 [1977]. Damonernes port. København: Hans Reitzel.

Hansen, E. \& L. Heltoft. 2011. Grammatik over det danske sprog. København: Syddansk Universitetsforlag.

Hansen, Aa. 1967. Moderne dansk III. København: Grafisk Forlag. 
Harder, P., L. Heltoft \& O.N. Thomsen. 1996. Danish directional adverbs. Content syntax and complex predicates: A case for host and co-predicates. E. EngbergPedersen, M. Fortescue, P. Harder, L. Heltoft, L.F. Jakobsen (red.), Content, expression and structure: Studies in Danish Functional Grammar, 159-198. Amsterdam: John Benjamins. DOI: 10.1075/slcs.29.07

Helmantel, M. 2002. Interactions in the Dutch adpositional domain. Utrecht: LOT.

Heltoft, L. 1992. The topology of verb second and SVO languages. A study in the sign functions of word order. Michael Herslund (red.), Word order (Copenhagen studies in language 15), 13-64. København: Handelshøjskolens Forlag.

Herslund, M. 1984. Particles, prefixes and preposition stranding. NyS, Nydanske Sprogstudier 14. 34-71.

Huddleston, R. \& G.K. Pullum. 2002. The Cambridge grammar of the English language. Cambridge: Cambridge University Press.

Hovmark, H. 2007. Danske retningsadverbier og rumlig orientering. Ph.d.-afhandling. Københavns Universitet.

Johnson, K. 1991. Object positions. Natural Language \& Linguistic Theory 9(4). $577-$ 636.

Jørgensen, H. 2014. Adverbiernes rækkefølge i henhold til Mikkelsen. O. Togeby, S. Vikner \& H. Jørgensen (red.), Problemer og perspektiver i dansk syntaks, 90 115. København: Syddansk Universitetsforlag.

Kayne, R.S. 1984. Connectedness and binary branching. Dordrecht: De Gruyter Mouton. DOI: 10.1515/9783111682228.

Kayne, R. 1985. Principles of particle constructions. J. Guéron, H-G. Obenauer \& J-Y. Pollock (red.), Grammatical representations, 101-140. Dordrecht: Foris.

Kobayashi, A. 2014. Postpositions in English. Eigo to Kyoiku (Engelsk og Uddannelse) 4. 13-35. https://ir.lib.shimane-u.ac.jp/files/public/3/36740/201704250210452 01276/eigotokyoiku4_13.pdf (tilgået 30. juni 2021).

Kobayashi, K. 1999. Another approach to bare-NP adverbials as nominals. English Linguistics 16(2). 353-380.

Krydstogtcenter.dk. u.å. https://krydstogtcenter.dk/destinationer/australien-og-newzealand/melbourne/ (tilgået 5. januar 2022).

KorpusDK. u.å. https://ordnet.dk/korpusdk (tilgået 14. april 2021).

Larson, R.K. 1985. Bare-NP adverbs. Linguistic Inquiry 16(4). 595-621.

Law, P. 1998. A unified analysis of P-stranding in Romance and Germanic. P. Tamanji \& K. Kusumoto (red.), Proceedings of the North Eastern Linguistic Society 28, 219-234. Amherst: Graduate Linguistics Student Association. 
Law, P. 2006. Preposition stranding. M. Everaert \& H.v. Riemsdijk (red.), The Wiley Blackwell companion to syntax, 631-684. Malden, MA: Blackwell Publishing.

Matsubara, F. 2012. Mapping spatial PPs: The cartography of syntactic structures. English Linguistics 29(2). 493-504. DOI: 10.9793/elsj.29.2_493.

Matsumoto, Y. 2013. On the historical development of preposition stranding in English. English Linguistics 30(1). 151-168. DOI: 10.9793/elsj.30.1_151.

McCawley, J.D. 1988. Adverbial NPs: bare or clad in see-through garb? Language 64(3). 583-590.

Mikkelsen, K.M. 1975 [1911]. Dansk ordföjningslare med sproghistoriske tillag. Håndbog for viderekomne og larere. København: Lehmann \& Stages Forlag.

Nguyen, M. 2018. On Danish Bare Nominal Adjuncts - a reply to Barrie and Yoo (2017). P.C.W. Lee, K.S. M. Leung, K.C. Li \& S.S.Y. Wong (red.), ICLLS 2018. Fourth International Conference on Linguistics and Language Studies, 143-157. Hongkong: Chartered Institute of Linguists Hong Kong Society. http://docs.wixstatic.com/ugd/2b7f97_12e298eb8c21496eba8c2c05fcf02cc3. pdf (tilgået 14. april 2021).

Nguyen, M. 2019a. Extraction of R-pronouns via an intermediate position within the prepositional domain. Snippets 35. 10-12. DOI: 10.7358/snip-2019-035-nguy.

Nguyen, M. 2019b. On some postpositional elements in Danish. I K.R. Christensen, H. Jørgensen \& J. Wood (red.), The sign of the V: Papers in honour of Sten Vikner, 449-465. Aarhus: Aarhus Universitet. DOI: 10.7146/aul.348.108.

Nguyen, M. 2019c. Lokative pronominer og præpositionalfrasens struktur. Ny Forskning i Grammatik 26. 122-140. DOI: 10.7146/nfg.v0i26.115997.

Nguyen, M. 2020a. A grammar of the adpositional phrase in Danish: On left located adpositional complements. Ph.d.-afhandling. Aarhus Universitet.

Nguyen, M. 2020b. Har dansk produktive postpositioner? Ny Forskning i Grammatik 27. 87-106. DOI: $10.7146 /$ nfg.v0i27.122133.

Nguyen, M. 2021a. Adpositionel brug af statiske retningsadverbier. M.H. Andersen \& E.S. Jensen (red.), Med fornøden agtelse. Festskrift til Jørgen Schack på 60-årsdagen 14. maj 2021 (Dansk Sprognævns skrifter 52), 221-237. Bogense: Dansk Sprognævn.

Nguyen, M. 2021b. Om præ- og postpositionel brug af fra. Y. Goldshtein, I.S. Hansen \& T.T. Hougaard (red.), 18. møde om udforskningen af dansk sprog, 417-435. Aarhus: Aarhus Universitet. 
Nguyen, M \& J.S. Østergaard. 2019. Om danske sted-adverbialer - med udgangspunkt i Barrie \& Yoo (2017). Y. Goldshtein, I.S. Hansen \& T.T. Hougaard (red.), 17. mode om udforskningen af dansk sprog, 357-378. Aarhus: Aarhus Universitet.

Ravsted Lokalhistorie. u.å. https://www.ravstedlokalhistorie.dk/index.php/erindringer /12-erindringer-ravsted/71-ravsted-fhv-skoleinspektor-johann-kirstens-barndomserindringer-fra-ravsted (tilgået 28. november 2021).

Riemsdijk, H. van. 1990. Functional prepositions. H. Pinkster \& I. Genee (red.), Unity in Diversity. Festschrift for Simon Dik, 229-241. Dordrecht: Foris.

Risom, K.B. 2005. Adverbial, lokativobjekt eller verbalpartikel? P. Widell \& M. Kunøe (red.), 17. møde om udforskningen af dansk sprog, 307-317. Aarhus: Aahus Univerisitet.

Rooryck, J. 1996. Prepositions and minimalist case marking. H. Thráinsson, S.D. Epstein \& S. Peter (red.), Studies in comparative Germanic syntax, bind 2, 226-256. Dordrecht: Kluwer Academic Publishers. DOI: 10.1007/978-94010-9806-9_9.

Svenonius, P. 2003. Limits on P: filling in holes vs. falling in holes. Nordlyd 31(2). 432-445. DOI: 10.7557/12.13.

Svenonius, P. 2007. Adpositions, particles and the arguments they introduce. E. Reuland, T. Bhattacharya \& G. Spathas (red.), Argument structure, bind 108, 63103. Amsterdam: John Benjamins. DOI: 10.1075/la.108.08sve.

Taraldsen, T. 2017. Places. M. Sheehan \& L.R. Bailey (red.), Order and structure in syntax II: Subjecthood and argument structure, 95-113. Berlin: Language Science Press.

Thomsen, O.N. 1998. Retningsadverbialer og komplekse prædikater i dansk. Selskab for Nordisk Filologi. Årberetning 1996-1997, 66-84. København: Selskab for Nordisk Filologi.

Togeby, O. 2003. Fungerer denne satning? Funktionel dansk sproglare. København: Gads Forlag.

Vergnaud, J-R. 1977. Letter to Noam Chomsky and Howard Lasnik. https://ling.auf. net/lingbuzz/000461 (tilgået 14. april 2021).

Vikner, S. 2013. C-kommando, koreference og negative polaritetselementer i dansk. I.S. Hansen, T.T. Hougaard \& P. Widell (red.), 14. møde om udforskningen af dansk sprog, 467-484. Aarhus: Aarhus Universitet.

Vikner, S. 2016. Verbalpartikelvariation i de germanske sprog. Ny Forskning i Grammatik 23. 233-252. DOI: 10.7146/nfg.v24i23.24654. 
Vikner, S. 2017. Germanic verb particle variation. E.O. Aboh, E. Haeberli, G. Puskás \& M. Schönenberger (red.), Elements of comparative syntax: Theory and Description, bind 127, 371-397. Berlin: Mouton de Gruyter. DOI: 10.1515/9781501504037-014.

Wurmbrand, S. 1998. Heads or phrases? Particles in particular. W. Kehrein \& R. Wiese (red.), Phonology and morphology of the Germanic languages, 267-295. Tübingen: Max Niemeyer Verlag. DOI: 10.1515/9783110919769.267.

Wurmbrand, S. 2000. The structure(s) of particle verbs. Manuskript. McGill University. http://citeseerx.ist.psu.edu/viewdoc/download?doi=10.1.1.462.2022\&rep =rep1\&type=pdf (tilgået 14. april 2020). 